\title{
Inverse Distance Weighted (IDW) Distribution Mapping of Phlebotomus papatasi, Phlebotomus tobbi, and Phlebotomus sergenti in Çukurova Region, Turkey
}

\author{
Levent BILLER*, Eren GERMEÇ
}

Çınar Engeneering, 1139. Street, Ankara, Turkey

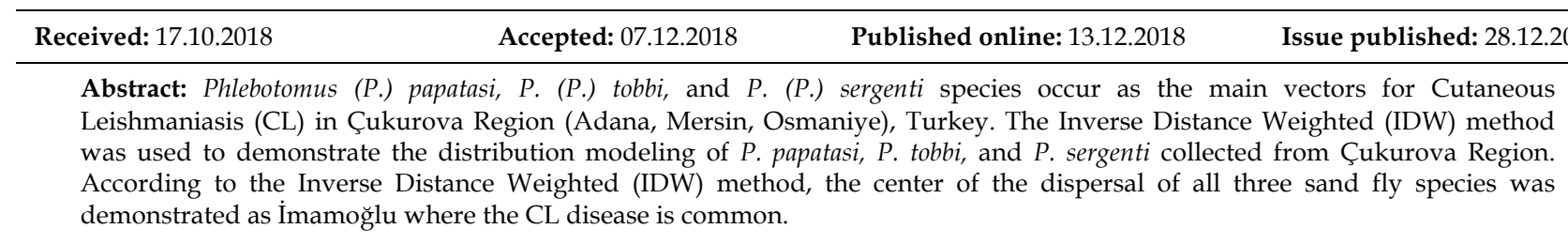

Keywords: inverse distance weighted, IDW, Phlebotomus papatasi, Phlebotomus tobbi, Phlebotomus sergenti, Çukurova, Turkey

Çukurova Bölgesindeki Phlebotomus papatasi, Phlebotomus tobbi ve Phlebotomus sergenti, Türlerinin Ters Uzaklık Ağırlıklı İnterpolasyon Yöntemi ile (IDW) Dağılışlarının Haritalanması

Öz: Phlebotomus (P.) papatasi, P. (P.) tobbi ve P. (P.) sergenti türleri kütanöz leşmanyöz'ün (CL) Türkiye'nin Çukurova Bölgesi'nde ana vektörleridir. Çukurova Bölgesi'nden (Adana, Mersin, Osmaniye) toplanan P. papatası, P. tobbi ve P. sergenti'nin dağılım modellemesi için ters uzaklık ağırlıklı interpolasyon (IDW) yöntemi kullanılmıştır. IDW yöntemi sonuçlarına göre CL hastalığının yaygın olduğu İmamoğlu üç kum sineği türü için dağılım merkezi olarak görülmektedir.

Anahtar kelimeler: ters uzaklık ağırlıklı interpolasyon yöntemi, IDW, Phlebotomus papatasi, Phlebotomus tobbi, Phlebotomus sergenti, Çukurova, Türkiye

\section{Introduction}

Leishmaniases are vector-borne diseases caused by flagellated protozoans of the genus Leishmania. This disease is endemic in large areas of the tropics, subtropics, and Mediterranean and is found in 98 countries. There are over 350 million people at risk and 12 million cases with an estimated worldwide annual incidence of 0.7-1.2 million cases of cutaneous leishmaniasis (CL) and 0.2-0.4 million cases of visceral leishmaniasis (VL). $29 \mathrm{VL}$ and $2465 \mathrm{CL}$ cases were reported per year between the years 2003 and 2007 in Turkey (Alvar et al., 2012). 14.587 CL and 207 VL cases were reported between the years 2005 and 2014 in Turkey (Gürel, Yeşilova, Ölgen, \& Özbel, 2012).

Two forms of Leishmaniasis are observed in Turkey; Leishmania infantum, L. tropica, L. major, and L. donovani cause CL (Serin et al., 2005; Koltas, Eroglu, Alabaz, \& Uzun, 2014) and L. infantum for VL. CL is highly endemic in southern southeastern Anatolia, whereas VL is endemic along the Aegean and Mediterranean coasts (Ozbel et al., 1995; Ok, Balcioglu, Taylan, Ozkan, Alkan, \& Ozbel, 2002; Volf et al., 2002; Yaman \& Ozbel, 2004). P. papatasi and $P$. sergenti are probable vectors of $L$. major and L. tropica in Turkey respectively (Alptekin et al., 1999; Pazarbasi, Alptekin, Luleyap, Kasap, \& Kasap, 2006; Volf et al., 2002); also, $P$. tobbi is the proven vector of $L$. infantum reported agent of CL in Turkey (Svobodová et al., 2009).

According to previous studies in Eirenis Region, $P$. papatasi Adler, P. tobbi Adler, Theodor et Lourie (1930) was found as the most abundant $(71.3 \%)$ species while $P$. sergenti Parrot (1917), the proven vector of L. tropica in Turkey, represented only $3 \%$ of the sand fly fauna (Alptekin et al., 1999; Volf et al., 2002; Yaman \& Ozbel, 2004; Simsek et al., 2007). According to the results of the recent investigations in this region, L. infantum Nicolle (1908) was collected from $P$. tobbi specimens for the first time (Svobodová et al., 2009). All these data show that further studies on the population distribution of sand fly species should be performed to reveal the risk of CL and VL in Turkey.

Data was taken from M.Sc. thesis of the first author between the years 2005 and 2007 and distribution maps were determined by using ArcGIS 10 (ESRI, 2011). For this purpose, inverse distance weighted (IDW) method was used. Inverse distance weighted (IDW) interpolation determines cell values using a linearly weighted combination of a set of sample points. This method assumes that the variable being mapped decreases in terms of the influence with distance from its sampled location (Philip \& Watson, 1982; Watson \& Philip, 1985).

This paper gives the results of an investigation to determine the species distribution in Çukurova Plain, Southern Anatolia, Turkey. Thus, it will give information about the possible distribution of Leishmaniasis in Çukurova Plain that will be effective for the control of CL and VL.

\section{Material and Methods}

\subsection{Study area}

Field studies were conducted in Çukurova Plain, South Anatolia from May to October between the years 2005 
and 2007. Sampling was made in 53 villages that are shown in Table 1and Fig. 1.

Table 1: Sampling stations' features

\begin{tabular}{|c|c|c|c|}
\hline \multirow{2}{*}{$\frac{\text { Village }}{\text { Kulak }}$} & \multicolumn{2}{|c|}{ Coordinates } & \multirow{2}{*}{$\begin{array}{r}\text { Height } \\
1 \mathrm{~m}\end{array}$} \\
\hline & N 364737.7 & E 345201.8 & \\
\hline Bahşiş & N 364936.2 & Е 345308.6 & $6 \mathrm{~m}$ \\
\hline Yaramış & N 364919.1 & E 350250.0 & $8 \mathrm{~m}$ \\
\hline Çağbaşı & N 365153.9 & Е 350353.4 & $15 \mathrm{~m}$ \\
\hline Yenice & N 365839.2 & E 350257.4 & $42 \mathrm{~m}$ \\
\hline Bebeli & N 363824.7 & E 352930.0 & $7 \mathrm{~m}$ \\
\hline Adalı & N 363804.8 & E 353233.0 & $7 \mathrm{~m}$ \\
\hline Yemişli & N 363918.6 & E 352131.0 & $9 \mathrm{~m}$ \\
\hline Eğriağaç & N 364640.8 & E 352650.4 & $9 \mathrm{~m}$ \\
\hline Cine & N 364749.0 & E 351537.9 & $10 \mathrm{~m}$ \\
\hline Hacı Hasan & N 364337.5 & E 351634.2 & $10 \mathrm{~m}$ \\
\hline Kiziltahta & N 364501.3 & E 353443.5 & $16 \mathrm{~m}$ \\
\hline Yalnızca & N 364631.6 & E 352453.8 & $18 \mathrm{~m}$ \\
\hline Doğankent & N 365051.9 & E 352019.0 & $20 \mathrm{~m}$ \\
\hline Dedepınarı & N 365536.6 & E 352856.4 & $4 \mathrm{~m}$ \\
\hline Ziyalı & N 364935.4 & E 353422.4 & $18 \mathrm{~m}$ \\
\hline Yumurtalık & N 364655.4 & E 354744.5 & $22 \mathrm{~m}$ \\
\hline Zeynepli & N 364414.4 & E 353443.5 & $25 \mathrm{~m}$ \\
\hline Çiftlikler & N 365852.6 & E 355234.5 & $26 \mathrm{~m}$ \\
\hline Narlık & N 365503.6 & E 355114.3 & $48 \mathrm{~m}$ \\
\hline İsalı & N 365511.9 & E 354304.9 & $63 \mathrm{~m}$ \\
\hline Belören & N 364842.2 & E 353320.9 & $99 \mathrm{~m}$ \\
\hline Baklalı & N 370211.2 & E 353816.6 & $124 \mathrm{~m}$ \\
\hline Çelemli & N 365048.1 & E 353902.4 & $162 \mathrm{~m}$ \\
\hline Küçük Tüysüz & N 370257.0 & E 360531.4 & $65 \mathrm{~m}$ \\
\hline Çağşak & N 370912.8 & Е 362002.9 & $184 \mathrm{~m}$ \\
\hline Tehci & N 370914.8 & Е 362001.9 & $192 \mathrm{~m}$ \\
\hline Sarımazı & N 365821.5 & E 355832.4 & $222 \mathrm{~m}$ \\
\hline Dutlupınar & N 370139.7 & Е 360103.7 & $222 \mathrm{~m}$ \\
\hline Tüysüz & N 370156.4 & Е 360441.5 & $228 \mathrm{~m}$ \\
\hline Akçakoyunlu & N 371115.4 & E 362513.3 & $373 \mathrm{~m}$ \\
\hline Düziçi & N 371552.6 & E 362827.1 & $530 \mathrm{~m}$ \\
\hline Kesmeburun & N 371552.9 & E 362827.0 & $530 \mathrm{~m}$ \\
\hline Karakütük & N 372440.1 & Е 360715.8 & $203 \mathrm{~m}$ \\
\hline Sofular & N 372253.9 & Е 361420.0 & $300 \mathrm{~m}$ \\
\hline Kızyusuflu & N 371954.8 & E 361236.7 & $373 \mathrm{~m}$ \\
\hline Aydinlar & N 372135.5 & Е 360045.1 & $45 \mathrm{~m}$ \\
\hline Bucak & N 372654.4 & E 355419.5 & $66 \mathrm{~m}$ \\
\hline Döşeme & N 372528.1 & Е 355159.2 & $175 \mathrm{~m}$ \\
\hline Güneri & N 372645.9 & E 354652.8 & $235 \mathrm{~m}$ \\
\hline Kızıllar & N 372843.8 & Е 354849.7 & $351 \mathrm{~m}$ \\
\hline Gedikli & N 373010.1 & E 355140.5 & $381 \mathrm{~m}$ \\
\hline Mercimek & N 370619.1 & E 354731.1 & $33 \mathrm{~m}$ \\
\hline Hamamköy & N 371908.7 & E 354902.8 & $45 \mathrm{~m}$ \\
\hline Tumlu & N 370849.9 & Е 354226.3 & $66 \mathrm{~m}$ \\
\hline Koyunevi & N 371721.3 & E 353923.6 & $146 \mathrm{~m}$ \\
\hline Camili & N 372019.5 & E 353638.5 & $181 \mathrm{~m}$ \\
\hline Tepecikören & N 372150.8 & Е 353738.9 & $189 \mathrm{~m}$ \\
\hline Otluk & N 371805.2 & E 353105.3 & $237 \mathrm{~m}$ \\
\hline Gökbüket & N 370739.1 & Е 353248.6 & $244 \mathrm{~m}$ \\
\hline Aydın & N 372435.6 & Е 353543.8 & $278 \mathrm{~m}$ \\
\hline Zerdali & N 372418.2 & E 353751.2 & $292 \mathrm{~m}$ \\
\hline Tepeçaylak & N 370333.6 & E 350334.7 & $188 \mathrm{~m}$ \\
\hline
\end{tabular}

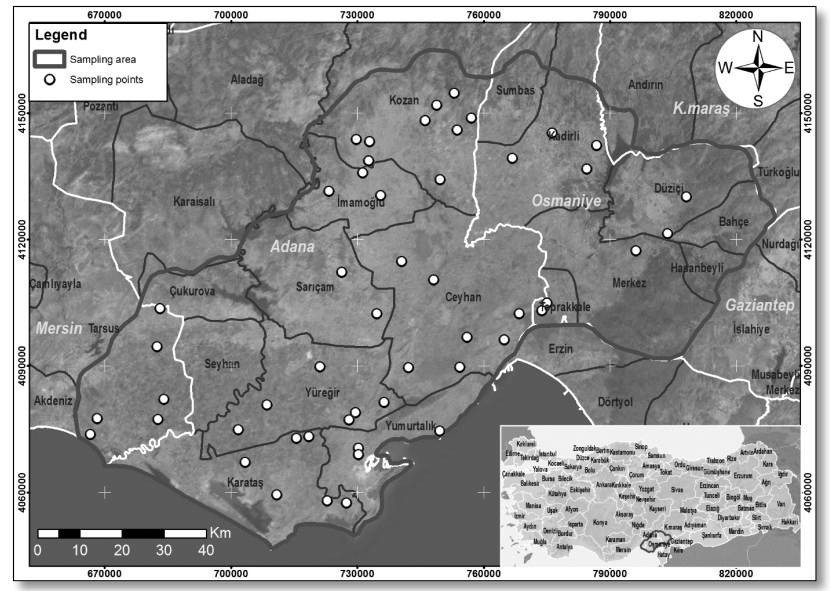

Figure 1: Map of sampling stations

\subsection{Collection methods}

Sand flies were collected monthly from May to October between 2005 and 2007 using one Centre for Disease Control (CDC) light trap (John W. Hock, USA) and one $\mathrm{CO}_{2}$ light trap (0.5 kg dry ice) in every location placed in yards and set up about $1.5 \mathrm{~m}$ above the ground for the whole night (between 20:00-06:00 hours). Four sticky paper traps $(20 \times 30 \mathrm{~cm}$ papers coated with castor oil $)$ were rolled up and placed in the holes of the wall that surrounds the animal shelters at every location. Moreover, indoor collections were performed by using mouth aspirators in the houses at every location.

\subsection{Sand fly identification}

Specimens collected from each trap were stored in $96 \%$ alcohol for morphological identification and further molecular studies. Identification was based on the morphology of the male genitalia and female spermatechae and pharynges using the keys of Theodor (1958), Artemiev (1980), Lewis (1982), and KillickKendrick et al. (1991).

\subsection{Inverse distance weighted (IDW)}

The Inverse Distance Weighing (IDW) interpolator is an automatic and relatively easy technique. It requires very few parameters, such as search neighborhood parameters, exponent and eventually smoothing factor (Hessl, Miller, Kernan, Keenum, \& McKenzie, 2007). The IDW directly applies the assumption that the un-sampled locations were average weighted from the known data points (Mitas, Mitasova, \& Brown, 1999) as in the following formula:

$$
Z_{j}=\frac{\sum_{i=1}^{n} \frac{Z_{i}}{\left(h_{i j}+\delta\right)^{\beta}}}{\sum_{i=1}^{n} \frac{1}{\left(h_{i j}+\delta\right)^{\beta}}}
$$

Where $\mathrm{Zj}$ is the value from an unsampled location, $\mathrm{Z} i$ are the known values, $\beta$ is the weight and $\delta$ is a smoothing parameter. The separation distance hij between a known and unknown point is measured with euclidean distance: 


$$
h_{i j}=\sqrt{(\Delta x)^{2}+(\Delta y)^{2}}
$$

where $\Delta \mathrm{x}$ and $\Delta \mathrm{y}$ are the distances between the unknown point $j$ and the sampled one $i$ according to reference axes.

IDW was determined by using ArcGIS 10 (ESRI, 2011).

\section{Results}

A total of 156 P. papatsi, 314 P. tobbi, and 84 P. sergenti species were collected. Of the collected total, $P$. tobbi was found to be the most abundant $(56.7 \%)$ species whereas $P$. papatasi the second abundant $(28.2 \%)$ and $P$. sergenti third abundant $(15.1 \%)$ of the total collected three species (Table 2).

Table 2: Abundance of the collected three species

\begin{tabular}{|c|c|c|c|c|c|c|}
\hline $\begin{array}{l}\stackrel{\mathscr{U}}{\tilde{\Xi}} \\
\text { के }\end{array}$ & & $\begin{array}{l}\text { :ँّ } \\
\text { कूँ } \\
\text { के }\end{array}$ & 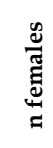 & 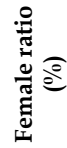 & $\begin{array}{l}\stackrel{\mathscr{ٌ}}{\widetilde{\Xi}} \\
\stackrel{\Xi}{\Xi}\end{array}$ & 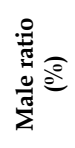 \\
\hline P. papatasi & 28.2 & 156 & 73 & 46.8 & 83 & 53.2 \\
\hline P. tobbi & 56.7 & 314 & 138 & 43.9 & 176 & 56.1 \\
\hline$P$. sergenti & 15.1 & 84 & 49 & 58.3 & 35 & 41.7 \\
\hline Total & & 554 & 260 & & 294 & \\
\hline
\end{tabular}

The species distribution in Çukurova Region is determined using IDW. The outcome of IDW and the results for $P$. papatasi, $P$. tobbi, and $P$. sergenti are given at figures below separately.

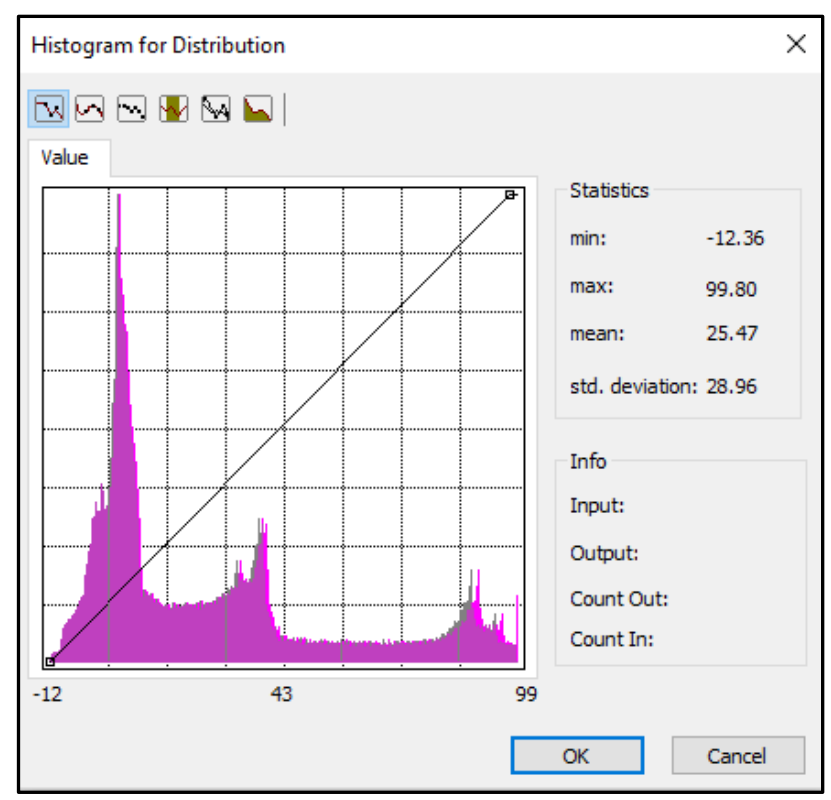

Figure 2: IDW results for $P$. papatasi

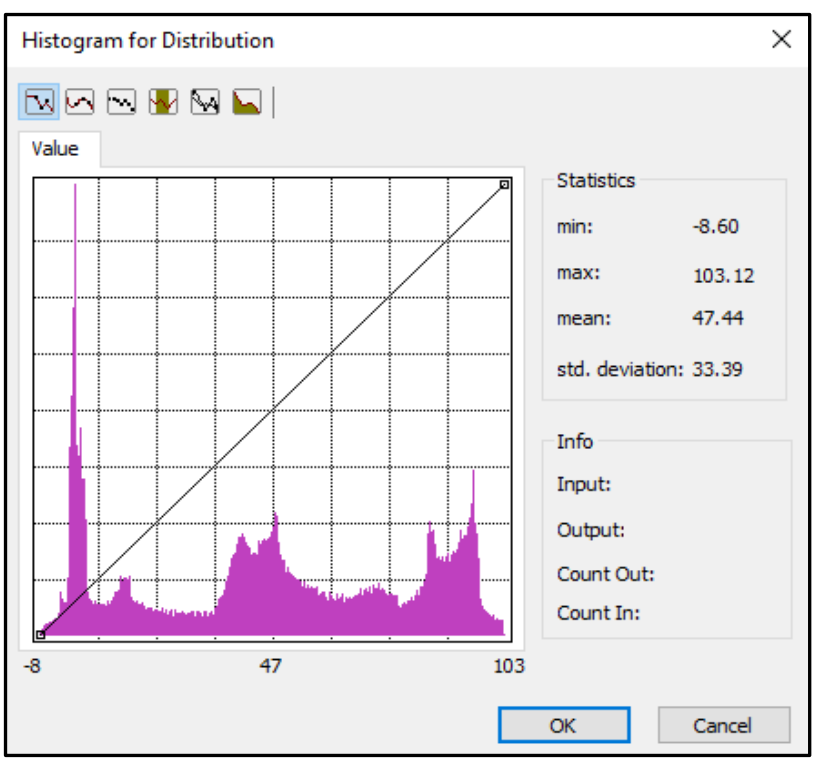

Figure 3: IDW results for $P$. tobii

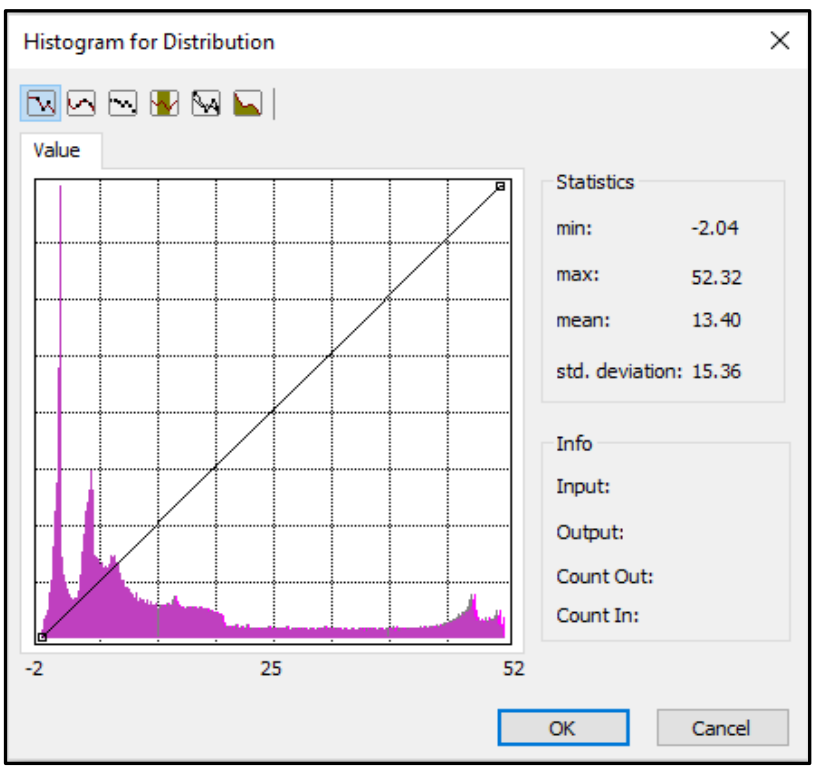

Figure 4: IDW results for $P$. sergenti

According to the graphs and statistics, above minimum, maximum, mean, and standard deviation for each species are given. Standard deviation for all three species is very high due to small sampling size; however, this does not affect the IDW. As shown in Fig. 2 and Fig. 3 , there are three main peaks that means the population of $P$. papatasi and $P$. tobbi are mainly distributed in three main points. On the otherhand, $P$. sergenti population is mainly distributed in two main points as shown in Fig. 4. 


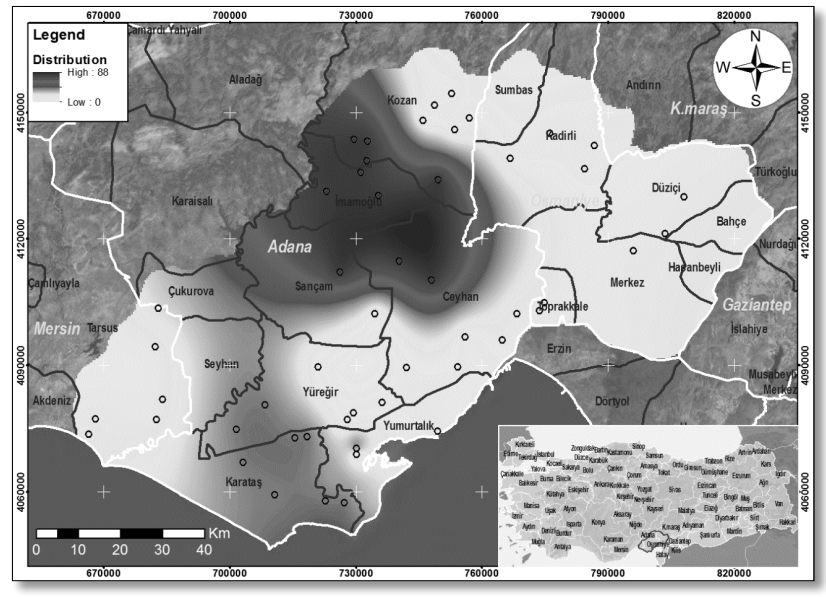

Figure 5: Distribution modeling using IDW for $P$. papatasi

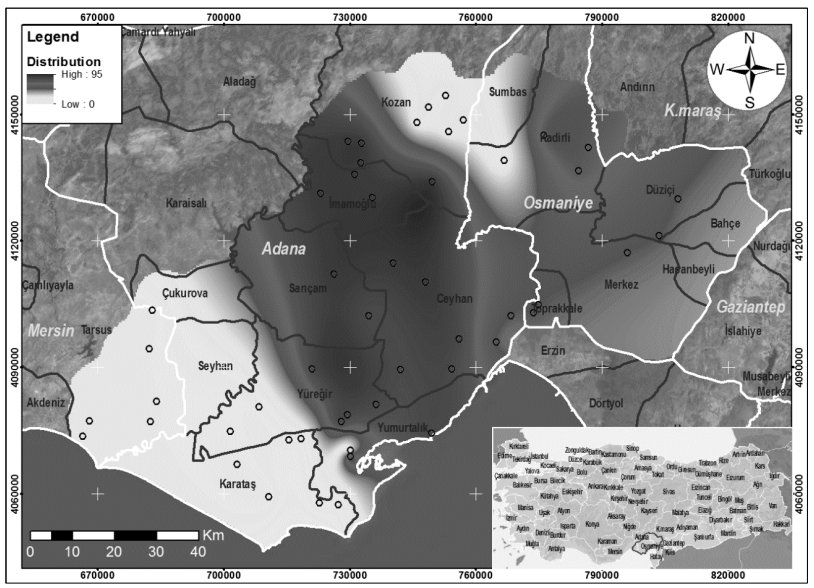

Figure 6: Distribution modeling using IDW for P. tobbi

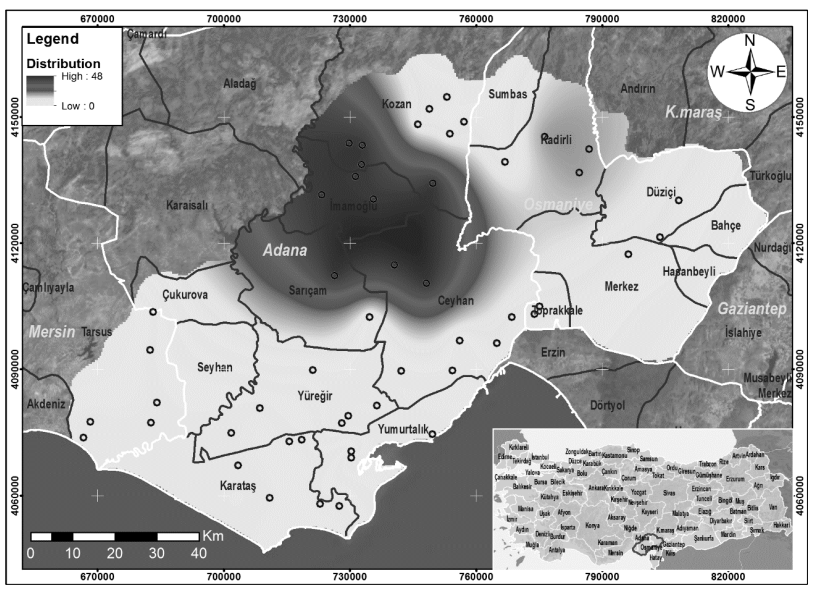

Figure 7: Distribution modeling using IDW for P. sergenti

\section{Discussion}

Phlebotomine sand flies are abundant and widespread in southern Anatolia with at least sixteen species present in the area. More importantly, all proven or suspected vectors of leishmaniasis in Turkey are also present (Alptekin et al., 1999; Volf et al., 2002; Yaman \& Ozbel, 2004; Toprak \& Ozer, 2005).

Simsek et al. (2007) disguised the distribution and altitudinal structure of sand flies in southern Anatolia, Turkey. According to the results 3172 sand flies were collected. In Çukurova Region, 105 sand flies were collected from Osmaniye and 1092 sand flies were collected from Adana. However, the locations were not identified. Therefore, a comparison of the distribution could not be made with our study.

Svobodova et al. (2009) worked at the western and eastern part of Çukurova Region, Turkey. According to the results, $P$. tobbi was dominant at the western $(82.56 \%)$ and the eastern $(81.34 \%)$ part of Çukurova Region, Turkey. Sampling areas were determined according to CL information of local health centers. In comparison to our results, $P$. tobbi shows the same results. According to the distribution modeling (see Fig. 6) of $P$. tobbi, two significant areas were identified. The western part where Tepecikören, Zerdali and Camili are the centers and eastern part where Boyali is the center. These results reflect similarity with the study of Svobodova et al. (2009). Moreover, P. papatasi was determined only at the western $(12.16 \%)$ part of Çukurova Region, Turkey. This result reflects overlap with our study. P. papatasi is mostly distributed at the western part of Çukurova Region, Turkey. P. sergenti was determined at the western $(0.8 \%)$ and at the eastern $(10.77 \%)$ part of Çukurova Region, Turkey. According to our study $P$. sergenti is more distributed at the western part than at the eastern part of Çukurova Region, Turkey.

Kavur and Artun (2017) map the risk areas for each sand fly species using remote sensing images in İmamoğlu, Adana. According to the results, three probable leishmaniasis vectors $(P$. tobbi, $P$. neglectus/syriacus, and P. perfiliewi) were identified. The spatial probability of $P$. tobbi was higher than the other species. According to the observation, the southwest part of İmamoğlu district had a high CL risk. The results of Kavur and Artun (2017) support the results of our study.

Kavur and Artun (2018) displayed the prevalence and incidence between 2009 and 2014 in Adana using GIS. According to the results the CL prevalence (20112014) and incidence (2011-2014) were found to be highest in İmamoğlu. This result reflects our distribution modeling for proven leishmania vectors.

In conclusion, the poor dispersal ability let to determine the possible diversity of $P$. papatasi, $P$. tobbi, and $P$. sergenti species. Nevertheless, the sampling size was small but an IDW mapping could be performed. Thus, it will give a possible distribution for Leishmaniasis risk areas in Çukurova Region. As shown in Fig. 5, Fig. 6, and Fig. 7, the dispersal center is İmamoğlu where the CL disease is common. In addition, it is important to notice that Leishmaniasis is transmitted with female sand flies. With these results, it can be decided which areas for disease control can be done more effectively.

Acknowledgments: This study was produced from M.Sc. Thesis of first author. The authors wish to thank Prof. Dr. Bülent Alten, Dr. Erişöz Kasap from Hacettep University, Faculty of Science, Department of Biology, Dr. Aslı Belen and Sinan Kaynaş for support and Prof. Petr Volf from Charles University, Parasitology Department for checking the species identified.

\section{References}

Alptekin, D., Kasap, M., Luleyap, U., Kasap, H., Aksoy, S., \& Wilson, M.L. (1999). Sand flies (Diptera: Psychodidae) associated with epidemic cutaneous leishmaniasis in Şanlıurfa, Turkey. Journal of Medical Entomology, 36, 277-281.

Alvar, J., Vélez, I.D., Bern, C., Herrero, M., Desjeux, P., Cano, J., Jannin, J., $\&$ den Boer, M. (2012). Leishmaniasis worldwide and global estimates of its incidence. PLoS ONE, 7(5), e35671. https://doi.org/10.1371/journal.pone.0035671. 
Artemiev M.M. (1980). A revision of sandflies of the subgenus Adlerius (Diptera, Phlebotominae, Phlebotomus). Zoologicheskii Zhurnal, 59, 1177-1192.

ESRI. (2011). ArcGIS Desktop: Release 10. Redlands, CA: Environmental Systems Research Institute.

Gürel, M.S., Yesilova, Y., Olgen, M.K., \& Ozbel, Y. (2012). Cutaneous leishmaniasis in Turkey. Turkiye Parazitoloji Dergisi, 36, 121-129. https://doi.org/10.5152/tpd.2012.29.

Hessl, A., Miller, J., Kernan, J., Keenum, D., \& McKenzie, D. (2007). Mapping Paleo-Fire Boundaries from Binary Point Data: Comparing Interpolation Methods, The Professional Geographer, 59(1), 87-104.

Kavur, H., \& Artun, O. (2017). Geographical Information Systems in Determination of Cutaneous Leishmaniasis Spatial Risk Level Based on Distribution of Vector Species in Imamoglu Province, Adana. Journal of Medical Entomology, 54(5), 1175-1182. https://doi.org/10.1093/jme/tjx102.

Kavur, H., \& Artun, O. (2018). Determination of Cutaneous Leishmaniasis Prevalence and Incidence, Between 2009-2014 in Adana by Using Geographical Information Systems. Earth Observation \& Surveying, Environmental Engineering, VII, 156-162.

Killick-Kendrick, R., Tang, Y., Killick-Kendrick, M., Sang, D.K., Sirdar, M.K., Ke, L., Ashford, R.W., Schorcher, J., \& Johnson, R.H., (1991). The identification of female sandflies of the subgenus Larroussius by the morphology of the spermathecal ducts. Parassitologia, 33(1), 335- 347.

Koltas, I.S., Eroglu, F., Alabaz, D., \& Uzun, S. (2014). The emergence of Leishmania major and Leishmania donovani in southern Turkey. Transactions of the Royal Society of Tropical Medicine and Hygiene, 108, 154-158. https://doi.org/10.1093/trstmh/trt119.

Lewis, D.J. (1982). A taxonomic review of the genus Phlebotomus (Diptera: Psychodidae), Bulletin of the British Museum (Natural History). Entomology, 45(2), 121-209.

Mitas, L., Mitasova, H., \& Brown, W.M. (1997). Role of dynamic cartography in simulations of landscape processes based on multivariate fields. Computers $\mathcal{E}$ Geosciences, 23, 437-46. https:// doi.org/10.1016/S0098-3004(97)00007-1.

Ok, U.Z., Balcioglu, I.C., Taylan Ozkan, A., Alkan, M.Z., \& Ozbel, Y. (2002). Leishmaniasis in Turkey. Acta Tropica, 84, 43-48

Ozbel, Y., Turgay, N., Ozensoy, S., Ozbilgin, A., Alkan, M.Z., \& Ozcel, M.A. (1995). Epidemiology, diagnosis and control of leishmaniasis in the Mediterranean region. Annals of Tropical Medicine, $\mathcal{E}$ Parasitology, 89, 89-93.

Pazarbasi, A., Alptekin, D., Luleyap, H.U., Kasap, M., \& Kasap, H. (2006). Use of enzyme-linked immunosorbent assay for detection of natural leishmania infections in phlebotomine sand flies from southeastern Turkey. Journal of Medical Entomology, 43(2), 248-51.

Philip, G.M., \& Watson D.F. (1982). A Precise Method for Determining Contoured Surfaces. Australian Petroleum Exploration Association Journal, 22, 205-212. https://doi.org/10.1071/AJ81016.

Serin, M.S., Daglioglu, K., Bagirova, M., Allahverdiyev, A., Uzun, S., Vural Z., Kayar, B., Tezcan, S., Yetkin, M., Aslan, G., Emekdas, G., \& Koksal F. (2005). Rapid diagnosis and genotyping of Leishmania isolates from cutaneous and visceral leishmaniasis by microcapillary cultivation and polymerase chain reaction-restriction fragment length polymorphism of miniexon region. Diagnostic Microbiology and Infectious Disease, 53, 209-2014. https://doi.org/10.1016/j.diagmicrobio.2005.05.007.

Simsek, F.M., Alten, B., Caglar, S.S., Ozbel, Y., Aytekin, A.M., Kaynas, S., Belen, A., Erisoz Kasap, O., Yaman, M., \& Rastgeldi, S. (2007). Distribution and altitudinal structuring of phlebotomine sandflies (Diptera: Psychodidae) in southern Anatolia, Turkey: their relation to human cutaneous leishmaniasis. Journal Vector Ecology, 32, 269-279.

Svobodová, M., Alten, B., Zídková, L., Dvořák, V., Hlavačková, J., Myšková, J., Šeblová, V., Erisoz Kasap, O., Belen, A., Votýpka, J., \& Volf, P. (2009). Cutaneous leishmaniasis caused by Leishmania infantum transmitted by Phlebotomus tobbi. International Journal for $\begin{array}{lr}\text { Parasitology, } & 39, \\ \text { https://doi.org/10.1016/j.diagmicrobio.2005.05.00710.1016/j.ijpara.20 }\end{array}$ $\begin{array}{lr}\text { Parasitology, } & 39, \\ \text { https://doi.org/10.1016/j.diagmicrobio.2005.05.00710.1016/j.ijpara.20 }\end{array}$ 08.06.016.

Theodor, O. (1958). Psychodidae-Phlebotominae. In E., Lindner (ed.), Die Fliegen Der Palaerktischen Region Lieferung 201, E. Schweizerbart'sche Verlagsbuchhandlung (Nagele u. Obermiller), Stuttgart, Germany., 1-55 pp.

Toprak, S., \& Ozer, N. (2005). Sand fly species of Sanliurfa province in Turkey. Medical and Veterinary Entomology, 19(1), 107-110. https:/ / doi.org/10.1016/j.diagmicrobio.2005.05.00710.1111/j.0269283X.2005.00545.x

Volf, P., Ozbel, Y., Akkafa, F., Svobodova, M., Votypka, J., \& Chang, K.P. (2002). Cutaneous leishmaniasis in Sanlıurfa, Turkey: Phlebotomus sergenti remains abundant with the decline of recent epidemic. Journal of Medical Entomology, 39, 12-15.
Watson, D.F., \& G.M. Philip. (1985). A Refinement of Inverse Distance Weighted Interpolation. Geoprocessing, 2, 315-327.

Yaman, M., \& Ozbel, Y. (2004). The sand flies (Diptera: Psychodidae) in the Turkish province of Hatay: some possible vectors of the parasites causing human cutaneous leishmaniasis. Annals of Tropical Medicine $\mathcal{E}$ Parasitology, 98, 741-750. https://doi.org/10.1016/j.diagmicrobio.2005.05.00710.1179/00034980 4225021415 . 